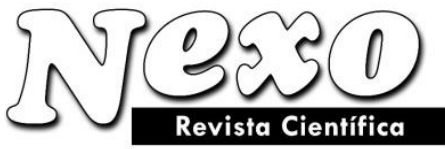

ISSN-E 1995-9516

Universidad Nacional de Ingeniería COPYRIGHT @ (UNI). TODOS LOS DERECHOS RESERVADOS

http://revistas.uni.edu.ni/index.php/Nexo https://doi.org/10.5377/nexo.v33i02.10797

\title{
Modernization of Two-Phase Oil and Gas Separator
}

\section{Modernización del separador de gas y petróleo de dos fases}

\author{
Guzel Rafikovna Ganieva ${ }^{1}$, Putu Aunda Niradgnani ${ }^{2}$ \\ ${ }^{1}$ Associate Professor (Department of development and operation of hard-to-recover hydrocarbon \\ deposits) Kazan Federal University. \\ ${ }^{2}$ Student Kazan Federal University, Institute of Geology and Oil and Gas Technologies, oil and \\ gas business.
}

\section{Corresponding author email: GGuzelRafikovna@mail.ru}

(recibido/received: 16-July-2020; aceptado/accepted: 19-September-2020)

\begin{abstract}
Separators play an important role in the basis of the technological scheme and field preparation of oil and gas. Separation is the process of oil separation from gas. Depending on the requirements for the feedstock, separators are distinguished according to the principle of operation and purpose. In this paper, the company "PT Pertamina EP Asset 3 Subang", Indonesia (Nirajani) is considered as an example. Dimensions, efficiency, reliability of equipment, capital and operating costs are the main indicators of separator work and productivity. "Subang PT Pertamina EP Asset 3 Subang" collection station has 3 horizontal two-phase separators (high pressure, low pressure and test separator). In 2020, it is planned to increase the extraction of raw materials. In this regard, the aim of this work is to modernize the existing two-phase horizontal separator operated at the field. To achieve this goal, it is necessary to study the design of the existing separator, and calculate its performance (Nirajani). After all the calculations, it is necessary to choose a separator suitable for performance. Modernization of the existing separator is economically feasible for this enterprise.
\end{abstract}

Keywords: oil, separator, multi-stage separator, horizontal separator, refining, associated petroleum gas, modernization.

\section{RESUMEN}

Los separadores juegan un papel importante en la base del esquema tecnológico y la preparación del campo de petróleo y gas. La separación es el proceso de separación del aceite del gas. Dependiendo de los requisitos de la materia prima, los separadores se distinguen según el principio de funcionamiento y el propósito. En este documento, la empresa "PT Pertamina EP Asset 3 Subang", Indonesia (Nirajani) se considera como un ejemplo. Las dimensiones, la eficiencia, la confiabilidad del equipo, los costos de capital y operativos son los principales indicadores del trabajo y la productividad del separador. La estación de recolección "Subang PT Pertamina EP Asset 3 Subang" tiene 3 separadores horizontales de dos fases (alta presión, baja presión y separador de prueba). En 2020, está previsto incrementar la extracción de materias primas. En este sentido, el objetivo de este trabajo es modernizar el separador 
horizontal bifásico existente operado en campo. Para lograr este objetivo, es necesario estudiar el diseño del separador existente y calcular su rendimiento (Nirajani). Después de todos los cálculos, es necesario elegir un separador adecuado para el rendimiento. La modernización del separador existente es económicamente viable para esta empresa.

Palabras clave: aceite, separador, separador multietapa, separador horizontal, refino, gas de petróleo asociado, modernización.

\section{INTRODUCTION}

Well production is a multicomponent mixture of hydrocarbons. As you know, the process of oil production is a complex technological chain. Each stage consists of certain installations, and it must be divided into phases (separation) for the rational use of raw materials. This method is used in the fields to stabilize oil. Partial separation of water from oil occurs in separation plants. Various separation equipment is used in the collection and preparation system, which, depending on the requirements for the feedstock, has various designs and models. Depending on the field, the fractional composition of the feedstock and the tasks of the equipment, separators are divided into stages.

The purpose of this work is to analyze the functionality of the existing two-phase separator in order to increase its productivity, due to the fact that production is planned to be increased at the field. To achieve this goal, it is necessary to solve the following tasks:

- analyze the kinds, types, and designs of two-phase separators;

- conduct a patent search and analysis of scientific articles on the modernization of two-phase separator (https://ifsolutions.com);

- select a related work as a prototype (Ganieva \& Timerkaev, 2017);

- study the technology of oil separation and develop recommendations for the modernization of existing equipment.

\section{METHODS}

Two types of separators are used in the fields - two-phase and three-phase. By design, the separators can be horizontal, vertical and spherical. If it is necessary to separate three liquids, such as gas, oil and water, three-phase separator is used. The number of phases refers to the number of streams leaving the separator, and not to the number of phases that are in the input stream. A two-phase separator is a separator in which the input stream is divided into two liquids at the outlet.

Some borehole streams contain sand or other solid particles that are removed in a separator. For the collection and disposal of solid materials, special internal devices are provided.

The function of a two-phase separator is to extract liquid from natural gas. Horizontal two-phase separators are widely used in industry. Liquid-liquid separators separate immiscible liquids into separate fractions due to differences in viscosity, interfacial tension, or specific gravity between the liquid components. Solids and liquid separators remove solids from liquids by centrifugation, the use of a semi-permeable medium (e.g. filters and membranes), or settling. The principle of separation is to distinguish between the sizes of the solid and liquid molecules of the mixture.

Two-phase separators have the same basic principle of operation as three-phase systems, but can only separate oil and gas mixtures. Like a three-phase system, it can be oriented as a horizontal two-phase separator or a vertical two-phase separator. A distinctive feature of two-phase 
horizontal and vertical separator is capacity. Due to their compactness, vertical two-phase separators can accommodate only smaller volumes of liquid, which require a shorter residence time.

Horizontal separators take up more space, and can handle large volumes of fluid at a time. Advantages and disadvantages of various types of separators.

Horizontal separators are smaller and cheaper than vertical separators for a given gas output. In the gravitational deposition section of a horizontal vessel, liquid droplets fall perpendicular to the gas flow and, thus, settle more easily from the continuous gas phase. Besides, since the interface area is larger in the horizontal separator than in the vertical separator, it is easier to reach the vapor space for gas bubbles that exit the solution when the liquid approaches equilibrium. Horizontal separators have a larger liquid capacity and are best suited for liquid-liquid separation and foaming.

Thus, horizontal separators are preferred for pure gas/liquid separation process. However, they have the following disadvantages that may lead to the preference of a vertical separator in certain situations:

1. Horizontal separators are not suitable for handling solids. The liquid discharge of the vertical separator can be placed in the center of the lower head, so that solid particles will not be accumulated in the separator, but continue until the next vessel in the process. Alternatively, a drainage system is installed so that solid particles can be periodically removed while the liquid leaves the vessel at a slightly higher level.

Several drains must be placed in a horizontal vessel along the entire length of the vessel. Since solids will have a repose angle from 450 to $60 \mathrm{o}$, the drains should be located at very short intervals. The attempts to increase the distance between the drains by creating sand jets near each drain hole for fluidization of solid particles during the operation of the drains are expensive and have achieved little success in field operations.

2. Horizontal vessels require more area to perform the same separation as vertical. Although this may not be significant on land, it can be very important at sea.

Horizontal vessels may have lower fluid throughput than vertical vessels designed for the same stationary flow rate. At a given change of the liquid surface height, the increase in liquid volume is greater for a horizontal separator than for a vertical separator calculated for the same flow rate. However, due to the geometry of the horizontal vessel, any high-level disconnecting device must be located close to the normal operating level. In a vertical vessel, the shutdown can be placed much higher, which allows the level controller and the pressure relief valve to respond more quickly to pumping. Besides, jumps in horizontal vessels can create internal waves that can activate a high-level sensor.

It should be noted that vertical vessels also have some disadvantages that are not related to the process and should be taken into account during selection.

1. The safety valve and some controls can be difficult to maintain without special stairs and platforms.

2. Due to height restrictions, a vessel may be removed from the cargo transportation platform.

In general, horizontal vessels are the most economical for the normal separation of oil and gas, especially in problem cases with emulsions, foam, or high gas-oil ratios. Vertical vessels operate most efficiently with a low gas/oil ratio. They are also used in some applications with a very high gas/oil ratio, such as scrubbers where only liquid mists are removed from the gas (Ampuero \& Castro, 2017). 


\section{RESULTS AND DISCUSSION}

All separators in Subang SS are in the form of flat (horizontal) two-phase separators, which means two phases, that are used only to separate gas and liquid (Figure 1).

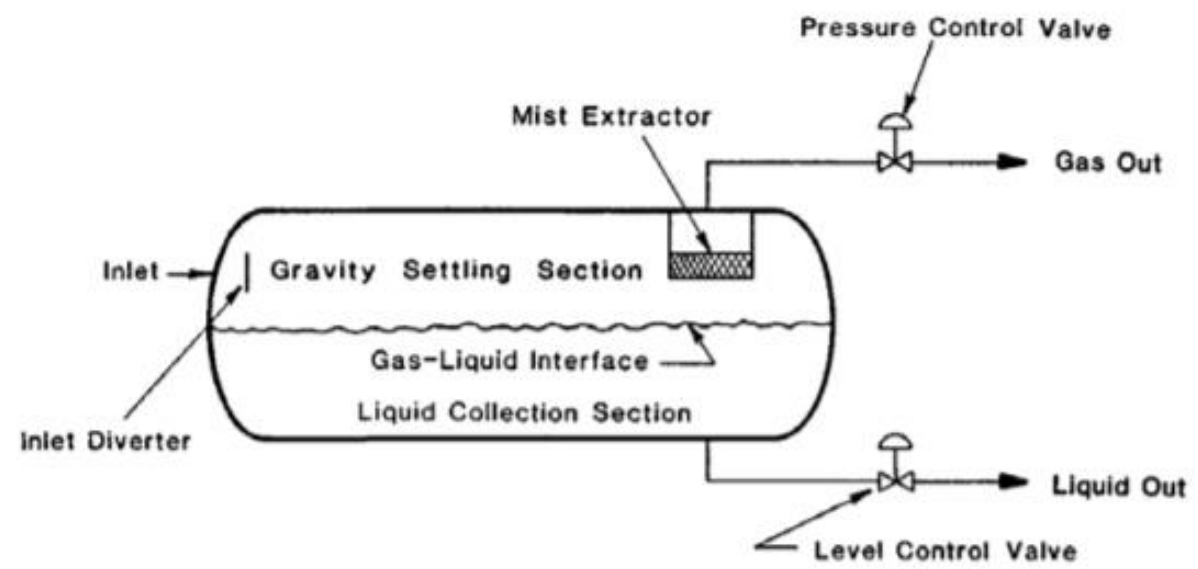

Figure 1: Separator circuit at a collection station Subang: Inlet; Inlet diverter ; Gravity settling section; Gas-liquid interface ; Liquid collection section; Mist extractor; Pressure control valve; Level control valve; Gas out; Liquid out.

The fluid enters the separator and the diverter inlet, causing a sudden change in momentum. The initial separation of steam and liquid occurs at the diverter inlet. The force of gravity causes droplets to fall from the gas stream to the separator bottom. Fluid collection section is at the separator bottom. This section presents the retention time required to separate the gas trapped in the oil and lift it into the gas chamber. Separators also provide pulsed volume to handle intermittent fluid flow. Then the liquid leaves the separator through the level control valve. This valve is used to control the liquid height in the separator by draining the liquid from the separator.

Gas enters the inlet deflector horizontally through the separation stage under the influence of gravity and is located in the upper part of the liquid. When gas flows through this section, droplets of liquid carried by this gas separate gravity, falling into the boundary layer between the gas and the liquid. Some liquids of small diameter are not easily separated by gravity. To do this, a mist extractor is added to collect small volume of liquid before the gas leaves the separator. This section uses a wire mesh to combine liquid droplets.

The separator pressure is maintained by a pressure regulator. The pressure regulator determines the separator pressure and sends a signal to the valve to open or close it so that the pressure matches the settings. By controlling the pressure in the separator by the means of gas flow, it is possible to maintain the pressure inside the separator. To maximize the surface area of the gasliquid interface, the separator works with a liquid containing half the height of the separator. To improve the performance of the separators in the fluid separation process, it is necessary to consider the separators available at the Subang collection station. One way to check is to recalculate the maximum capacity limit of the separators available in the field. Moreover, it is also very necessary to calculate the separator new design, which will be used in accordance with the production goal of "PT Pertamina EP Asset 3 Subang", which provides 1100 barrels of liquid per day $(174.89 \mathrm{~m} 3 /$ day). According to the results of the review, an alternative separator design and type will be obtained at the Subang collection station. Based on the data given in table 1, you 
can analyze the design of the proposed separator. According to the data shown in table 1 , production by 1100 barrels of fluid per day (174.89 m3/day) is obtained by increasing the length of separator.

Calculation and analysis results are expected to guide "PT Pertamina EP Asset 3 Subang" during separator installation in accordance with the company specified manufacturing objectives. According to industry practice, the separator type used at the Subang PT collection station "Pertamina EP Asset 3 Subang" is a horizontal separator with the dimensions of $1.31 \mathrm{~m}$ (diameter) x $2.438 \mathrm{~m}$ (length). The use of a horizontal separator at the Subang collection station complies with all operating standards. According to the physicochemical characteristics, the oil produced at the Subang field is classified as normal oil, which confirms the value of oil gravity = $34.19 \mathrm{oAPI}$. The production capacity of the separator at the Subang collection station for one year (April 2019 - March 2020) makes 569.963 barrels of fluid per day (90.62 m3/day). In connection with the drilling of a new well in 2020 (Ampuero \& Castro, 2017), the company expects production increase by 1100 barrels of fluid per day (174.89 m3/day).

Table 1: Analysis of the design of a horizontal separator in the production of 1,100 barrels of fluid per day (174.89

\begin{tabular}{|c|c|c|c|c|}
\hline \multirow{2}{*}{ № } & \multicolumn{2}{|c|}{ Separator design } & \multirow{2}{*}{$\begin{array}{c}\mathrm{Q}_{\mathrm{f}}\left(\mathrm{m}^{3} / \mathrm{day}\right) \\
\text { (Fluid flow) }\end{array}$} & $\begin{array}{c}\mathrm{R}_{\mathrm{m}} \\
\text { (area ratio) }\end{array}$ \\
\cline { 2 - 3 } & Length $(\mathrm{m})$ & Diameter $(\mathrm{m})$ & 174,89 & 2,7917 \\
\hline 1 & 2,438 & 0,873 & 174,89 & 3,1407 \\
\hline 2 & 2,743 & 0,873 & 174,89 & 3,4897 \\
\hline 3 & 3,048 & 0,873 & 174,89 & 3,8387 \\
\hline 4 & 3,353 & 0,873 & 174,89 & 4,1876 \\
\hline 5 & 3,657 & 0,873 & & \\
\hline
\end{tabular}

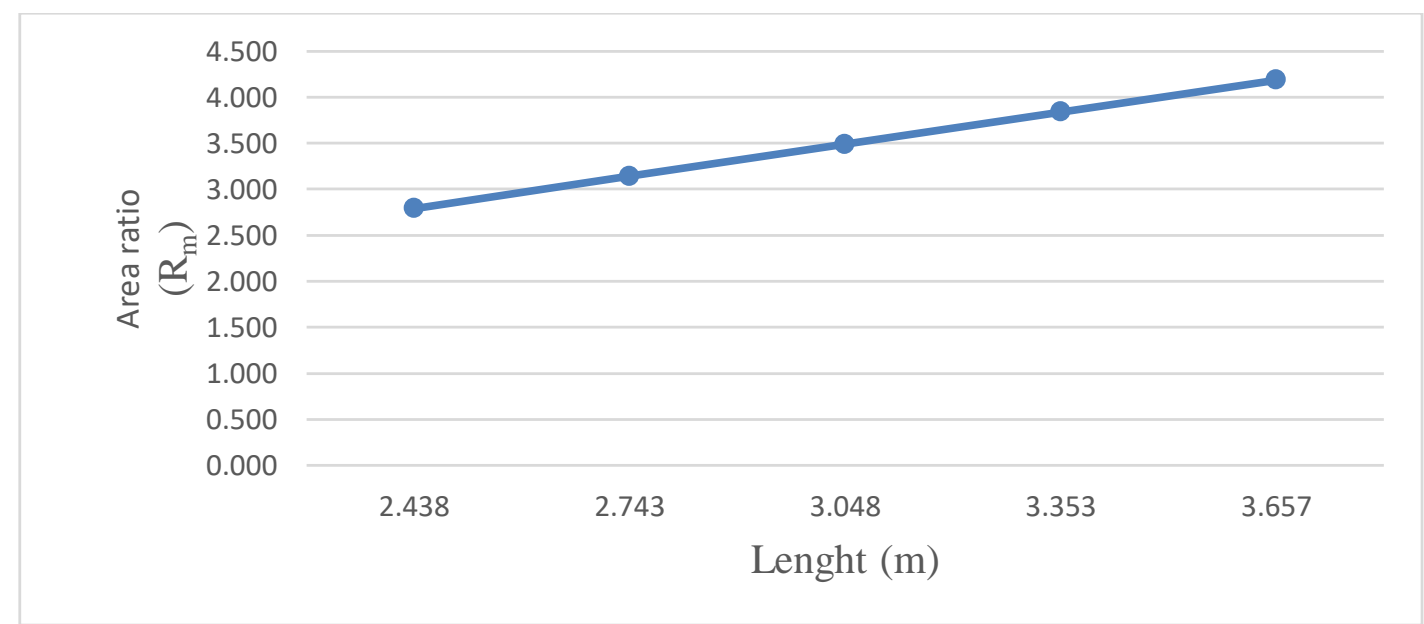

Figure 2: Analysis of the design diagrams of horizontal separators in the production of 1,100 barrels of fluid per day (174.89 m3 / day)

\section{CONCLUSIONS}

To modernize the existing separator of the Subang collection station, it is necessary to study its technological characteristics, the data is presented below.

Size - $1.31 \mathrm{~m}$ (diameter); 2,438 m (length) 
Type - Horizontal

Design pressure - 4.0058 $\mathrm{MPa}$

Design Temperature $-51.667{ }^{\circ} \mathrm{C}$

Corrosion tolerance $-3.175 \mathrm{~mm}$

Maximum allowable working pressure $-4.0058 \mathrm{MPa}$ at $51.667^{\circ} \mathrm{C}$

Year of product manufacture - 2001

For further work, it is necessary to recalculate the maximum limit of separator capabilities available in the field. This calculation is necessary to determine the separator new design. Calculation and analysis results are expected to guide "PT Pertamina EP Asset 3 Subang" during separator installation in accordance with the specified company manufacturing objectives.

After calculation and selection, we get the following:

1. Horizontal separators of $1.31 \mathrm{~m}$ (diameter) $\times 2.438 \mathrm{~m}$ (length) installed in the field are able to accommodate 800 barrels of fluid per day (127.19 m3/day). Therefore, to increase production by 1100 barrels of fluid per day $(174.89 \mathrm{~m} 3 /$ day $)$ it is necessary to change the design.

2. The performance of a horizontal separator proposed design makes 1100 barrels of fluid per day (174.89 m3/day).

The initial total income before the separator modernization and the target total income after the separator modernization are presented in economic calculations. According to the data obtained (February 2020), 4,781 barrels of oil per day (760.12 m3/day) and 197.2 million standard cubic feet pf gas per day ( $5578418.78 \mathrm{~m} 3 / \mathrm{s})$ were produced at the "PT Pertamina Asset 3 Subang field" (Pertamina, 2020).

After drilling new oil wells in Subang, the goal of additional production is planned to be increased to 1,100 barrels of fluid per day.

After calculations, instead of replacement of the old equipment with new, it is proposed to change the separator design, i.e. increase the length. as concluded, production by 1100 barrels of fluid per day (174.89 m3/day) was gaind by increasing the length. This approach is effective from an economic point of view.

\section{SUMMARY}

As you know, separators play a significant role in the collection, preparation and processing of associated hydrocarbon feedstock. Dimensions, efficiency and reliability of equipment, capital, operating costs are the main indicators of the separator work and performance. "Subang PT Pertamina EP Asset 3 Subang" collection station has 3 horizontal two-phase separators (high pressure, low pressure and test separator). According to the calculation performed above, it was found that the estimated gross income of the Subang field after the modernization of three separators will be 66695743,167 US dollars.

\section{ACKNOWLEDGEMENTS}

The work is performed according to the Russian Government Program of Competitive Growth of Kazan Federal University. 


\section{REFERENCES}

Ampuero, J.F.I., \& Castro, A.J.C. (2017). Design of Oil-Gas Separators - From Hydrocarbon Stream. Lima, Peru. Universidad Nacional de Ingeniera. URL: http://acreditacion.uni.edu.pe/wp-content/uploads/2017/05/Design-of-OilGas-Separators-\%E2\%80\%93-From-Hydrocarbon-Stream.pdf

Bianco, R. Encyclopaedia of hydrocarbon. Volume 1/ Exploration and transport.(CITATION)

DXP. Two Phase Separator vs. Three Phase Separator Differences. 2019. URL: https://ifsolutions.com/two-phaseseparator-vs-three-phase-separator-differences/ (reference date: 20.05.2020)

Ganieva, G. R., \& Timerkaev, B. A. (2017). Electroarc vapourtron for bitumen extraction and transportation. IOP Conf. Series: Journal of Physics: Conf. Series, 789, 012013

Nirajani

A. Thesis.

URL:

https://kpfu.ru/student_diplom/10.160.178.20_7P30_3D_GWVEWKA0F_TVL5JXAOTGX01MZWQDK3I_D3J2B

_QX77_F_Niradzhnani_Ayunda_P._gr.03_608.pdf

Pertamina, E.P. (2020). Asset 3 Subang Field Sukses Tingkatkan Produksi Migas. URL: https://www.pertamina.com/id/news-room/news-release/pertamina-ep-asset-3-subang-field-sukses-tingkatkanproduksi-migas (Reference date: 29.05.2020) 